\title{
Immigration System, Labor Market Structures, and Overeducation of High-Skilled Immigrants in the United States and Canada
}

\author{
Yao Lu, Columbia University \\ Feng Hou, Western University, Ontario, Canada
}

\section{Full citation:}

Lu, Yao, and Feng Hou. "Immigration System, Labor Market Structures, and Overeducation of High-Skilled Immigrants in the United States and Canada." International Migration Review 54(4):1072-1103.

\section{Correspondence:}

Yao $\mathrm{Lu}$

501 Knox Hall

606 West 122nd Street

New York

USA

Email: yao.lu@columbia.edu

\section{Acknowledgments:}

The authors thank Garnett Picot, analysts at the Research and Evaluation Branch of Immigration, Refugees and Citizenship Canada, the anonymous reviewers and the editors for valuable feedback. Lu gratefully acknowledges support from the National Science Foundation (SES1226546). 


\title{
Immigration System, Labor Market Structures, and Overeducation of High-Skilled Immigrants in the United States and Canada
}

\begin{abstract}
Why do high-skilled Canadian immigrants lag behind their US counterparts in labor-market outcomes despite Canada's merit-based immigration selection system and more integrative context? This article investigates a mismatch between immigrants' education and occupations, operationalized by overeducation, as an explanation. Using comparable data and three measures of overeducation, we find that university-educated immigrant workers in Canada are consistently much more likely to be overeducated than their US peers and that the immigrant-native gap in the overeducation rate is remarkably higher in Canada than in the United States. This article further examines how the cross-national differences are related to labor-market structures and selection mechanisms for immigrants. Whereas labor-market demand reduces the likelihood of overeducation in both countries, the role of supply-side factors varies: a higher supply of university-educated immigrants is positively associated with the likelihood of overeducation in Canada but not in the United States, pointing to an oversupply of high-skilled immigrants relative to Canada's smaller economy. Also, in Canada the overeducation rate is significantly lower for immigrants who came through employer selection (i.e., those who worked in Canada before obtaining permanent residence) than for those admitted directly from abroad through the point system. Overall, the findings suggest that a merit-based immigration system likely works better when it takes into consideration domestic labor-market demand and the role of employer selection.
\end{abstract}




\section{INTRODUCTION}

Canada and the United States are two major immigrant destinations marked by distinct immigration policies (Bloemraad 2011). Canada's immigration system heavily rewards human capital, whereas the central pillar of US policy has been family reunification (Greenwood and McDowell 1991). This major difference has prompted both academics and policy makers to undertake comparisons of the two countries (e.g., Antecol et al. 2003; Kaushal and Lu 2015). As the Trump administration contemplates an overhaul of US immigration policies, many politicians and commentators point to Canada's merit-based system as a shining example of a positive immigration strategy (Roubein 2014; Pierce and Selee 2017). The RAISE Act, for example, which was introduced in the US Senate in 2017, cites the Canadian system as a possible model for achieving its goal of reducing family-based admissions and increasing merit-based immigration (Pierce and Selee 2017). The rationale for a merit-based system in the United States is that highly educated immigrants are a more productive economic force and more likely than low-skilled immigrants to integrate successfully into the host society (Hunt and GauthierLoiselle 2010).

Given the current immigration debate in the United States, it is important to obtain a fuller understanding of how the US and Canadian immigration systems function, especially the potential pitfalls of a merit-based immigration system. To this end, this article examines the relative labor-market performance of high-skilled immigrants in the two countries, operationalized by education-occupation mismatch of university-educated immigrants. ${ }^{1}$ The USCanada comparison is facilitated by the fact that the two countries have similar democratically

\footnotetext{
${ }^{1}$ We use the term education-occupation mismatch and overeducation interchangeably in the article.
} 
elected government, similar economic systems, and geographic proximity, but substantial differences in immigration policies (Bloemraad 2011). ${ }^{2}$

Existing comparative research on the United States and Canada generates both expected and unexpected findings (Kaushal and Lu 2015; Bonikowska, Hou, and Picot 2011). As expected, Canada's point-based system has generated a greater proportion of immigrants with high levels of education and professional credentials (Kaushal and Lu 2015). Canada also has implemented pre- and post-arrival programs to ease immigrants' settlement and integration (Bloemraad 2006). These programs include language training and early settlement support, as well as funding for community-based organizations that provide employment counseling and other social assistance (Bloemraad 2006). By contrast, the United States has no formal federal policy on immigrant integration (Bloemraad and De Graauw 2012). These differences would predict greater labor-market success for immigrants in Canada compared to their US peers. Nevertheless, the literature documents the opposite: immigrants in Canada lag behind their US peers in a range of labor-market outcomes (Bonikowska et al. 2011; Picot and Hou 2003; Aydemir and Skuterud 2005). This pattern holds even when comparing university-educated immigrants from the same source country and accounting for individual unobserved heterogeneity (Kaushal et al. 2016).

Education-occupation mismatch is one plausible explanation for immigrants' relative labor-market disadvantage in Canada, where immigrants may be more likely settle into

\footnotetext{
${ }^{2}$ There is one important institutional difference between the two countries (Boyd 2014). In Canada's parliamentary system of governance, decision-making power lies in the executive rather than the legislature branch of government. By contrast, the congressional system in the United States is characterized by competing demands of multiple political parties. This difference partly explains the continuing immigration policy developments in Canada over the last several decades and the impasse of legislations to enact comprehensive immigration reform in the United States during the same time period (Boyd 2014).
} 
occupations for which they are overqualified. It is operationalized by overeducation, which is defined as a worker's education being greater than the education level required to adequately perform the job. This article's goal is to assess the degree of overeducation among high-skilled immigrants in the United States and Canada and to examine structural factors contributing to observed cross-country differences in overeducation. Although immigrant overeducation has been studied in both a US and a Canadian context (Banerjee et al. 2018; Beckhusen et al. 2013; Boyd 2013; Chiswick and Miller 2009; Frank 2013; Girard and Smith 2013; Mattoo et al. 2008; McDonald et al. 2015; Wald and Fang 2008), we offer one of the first systematic comparisons of the level and explanations of overeducation between immigrants in the two countries.

The article proceeds in three stages. First, we draw on comparable data from the American Community Survey and the Canadian Census to calculate the rate of overeducation for native-born and immigrant workers in each country ${ }^{3}$ and to explicitly compare the overeducation rate for immigrant workers across the two countries. For robustness purposes, we rely on three different ways of defining overeducation. Second, we investigate what factors underlie the differential rates of overeducation among immigrants in the two countries. This analysis is based on the premise that immigration policies interact with structural features of destination labor markets to affect skilled immigrants' economic performance. ${ }^{4}$ We focus on key structural economic factors - namely, labor-market supply and demand. On the supply side, Canada has outpaced the United States in the share of university-educated immigrants in the labor force (Kaushal and Lu 2015). On the demand side, however, Canada has one-tenth the size of the US economy and a less knowledge-intensive industrial structure (Baldwin and Willox 2016).

\footnotetext{
${ }^{3}$ We study immigrant and native-born workers in this article (i.e., those with a job). For simplicity, we use immigrants and the native-born to denote immigrant and native-born workers throughout the text. ${ }^{4}$ We focus on skilled immigrants because merit-based immigration policies are mainly relevant for this group.
} 
Therefore, compared with the United States, Canada has a larger supply of university-educated immigrants relative to labor market demand for skilled workers. This imbalance could have important implications for overeducation among immigrants in Canada.

Third, we explore immigrant selection mechanisms that can promote immigrants' education-occupation match. To do so, we compare the level of overeducation among highskilled immigrants admitted under different admission mechanisms in Canada. Although most skilled immigrants to Canada are admitted through the point system, there are other mechanisms through which immigrants are jointly selected by employers and the point system (Pandey and Townsend 2011). Different selection mechanisms have distinct consequences for the alignment between labor-market supply with demand for skilled workers and, hence, the risk of overeducation among immigrants. To conclude, we find that university-educated recent immigrants in Canada have a much higher overeducation rate than those in the United States, and the large gap is partly related to Canada's relative oversupply of skilled immigrants and crosscountry differences in immigration selection.

\section{IMMIGRATION POLICIES AND IMMIGRANT CHARACTERISTICS}

A key institutional difference between the United States and Canada is immigration policy, which, since the mid-1960s, has diverged in significant ways in the two countries (Boyd 1976; Greenwood and McDowell 1991). The United States has maintained a policy oriented toward family reunification, following the Immigration Act of 1965, which eliminated nationalityspecific quotas (Daniels 2005). The policy, which is broader than that of many other countries

(Greenwood and McDowell 1991), allows for the immigration of a range of family members of 
permanent residents and citizens, with no limit on the number of admittances for immediate relatives of US citizens (Daniels 2005).

By contrast, in 1967 Canada adopted a point system that selects economic immigrants, based primarily on human capital factors and labor-market demand (Bloemraad 2011). In 1993, the point system was modified to enhance a human capital approach that places greater emphasis on educational attainment and English/French language proficiency and less emphasis on the attempt to match immigration levels to perceived labor shortages in specific occupations (Hou and Picot 2016). The 2002 Immigration and Refugee Protection Act (IRPA) further augmented Canada's human-capital approach and eliminated points assigned for specific highdemand occupations (Ferrer, Picot, and Riddell 2014). In 2015, Canada introduced the Express Entry system to increase the efficiency of economic immigrant selection (Hiebert 2019). This new system for screening applicants puts more emphasis on Canadian work experience while maintaining the importance of language ability and education (Hou and Lu 2017).

The United States also has economic immigration programs, which operate mainly through employer sponsorship, particularly after the 1990 Immigration Act (Daniels 2005). The screening mechanism for the "employment-based" preference system involves two steps. First, skilled foreign workers are recruited by US employers through temporary work visas (e.g., the H-1B visa), and second, they may transition to permanent residency via employer sponsorship (Daniels 2005). From 1992 to 2015, the number of H-1B visas - a type of employment-based visa for temporary workers in specialty occupations who have at least a bachelor's degree or its equivalent - increased almost fivefold (USCIS 2017). Nevertheless, the proportion of economic-class immigrants has remained relatively small in the United States 
compared to Canada. ${ }^{5}$ Less than $20 \%$ of immigrants in the United States, but more than $50 \%$ of immigrants in Canada, entered as economic-class immigrants in mid-2010s (Kaushal et al. 2016).

These policy differences produce different human capital profiles of immigrants. Canada's point system has resulted in the arrival of immigrants from specific sending regions, especially Europe and Asia (compared to Latin America for the United States), and with more favorable characteristics, including higher education levels and English/French proficiency (Kaushal and Lu 2015). For example, in 1990, 22\% of Canadian immigrants arrived with university degrees; by 2005, that percentage had more than doubled to $52 \%$ (Kaushal and Lu 2015). The timing of this change is broadly consistent with immigrant selection policy reforms in the 1990s and early 2000s that put a greater emphasis on human capital in Canada (Hou and Picot 2016). By contrast, in the United States, the percentage of university-educated immigrants rose much more moderately during the same period, from $28 \%$ to $33 \%$ (Kaushal and Lu 2015). Although the Canadian point system has resulted in positive selection on observable human capital traits, it is less clear how immigrants in the two countries differ in unobserved skills (i.e., outside the point system's domain). Previous research suggests that the destination labor market's features shape immigrant self-selection (Borjas 1987; Cohen and Haberfeld 2007; Grogger and Hanson 2011). For instance, the greater the return to human capital, the more likely that immigrants are positively selected. In this respect, Canada's more egalitarian wage structure, coupled with its relatively generous welfare system, may render it less attractive for highly

\footnotetext{
${ }^{5}$ One difference to note is that the United States has a large-scale undocumented immigrant population (about 10.5 million, or one fourth of all immigrants), primarily from Mexico (Krogstad, Passel, and Cohn 2019). The magnitude of undocumented immigration in Canada is much smaller, with estimates somewhere between 20,000 and 500,000, or less than 8\% of total immigrants (Magalhaes, Carrasco, and Gastaldo 2010). This article's focus on high-skilled immigration means that undocumented immigrants are unlikely to be a major issue in our analysis.
} 
skilled immigrants than the United States, where returns to education are higher (Bonikowska et al. 2011). However, empirical research suggests that unobserved qualities may not be a major explanation for cross-national differences in immigrant outcomes. Using longitudinal data to adjust for stable unobserved qualities among immigrants, Kaushal et al. (2016) find that immigrants' relative wage advantage in the United States remains. The limited role of immigrant selectivity suggests that to understand immigrant labor-market outcomes, we must examine not only individual characteristics but also factors in the broader labor market (Antecol et al. 2003).

\section{LABOR-MARKET STRUCTURES, IMMIGRATION SYSTEM, AND OVEREDUCATION}

At the broader level, we propose that immigration policies combine with labor-market structures to affect immigrants' labor-market outcomes. Canada's immigration system creates large-scale skilled immigration relative to its population size. In 2016, annual permanent migration to Canada $(0.82 \%$ of the population) was more than double the annual permanent migration to the United States $(0.37 \%$ of the population $) .{ }^{6}$ The US economy, however, is more than 10 times the size of the Canadian economy (World Bank 2017), and in 2016, US GDP was about 12 times that of Canada (World Bank 2017). Over the 1990s, economic growth in the United States was driven mostly by university-educated workers, whereas in Canada the driving force was nonuniversity workers (Ho, Rao, and Tang 2004). These different growth patterns imply that Canada has had a weaker demand for skilled workers than the United States over the past two decades.

\footnotetext{
${ }^{6}$ Authors' calculation based on US and Canadian immigration statistics and population estimates from the following sources: https://www.dhs.gov/immigration-statistics/yearbook/2015/table1, https://www.census.gov/data/tables/2017/demo/popest/nation-total.html\#par textimage 2011805803, https://www150.statcan.gc.ca/t1/tbl1/en/tv.action?pid=1710000501, and Facts and Figures 2016 http://www.cic.gc.ca/opendata-donneesouvertes/data/Facts and Figures_2016 PR EN.pdf(last accessed, October 2 2019).
} 
These macroeconomic conditions suggest a possible misalignment in Canada between the large supply of university-educated immigrants and the relatively small demand for skilled labor. This structural imbalance may inhibit Canada's ability to absorb skilled immigrants, especially in high-skilled occupations commensurate with immigrants' education. Hence, we expect that skilled immigrants in Canada are more likely to experience overeducation than their US counterparts. We also expect the risk of overeducation to vary by immigrants' length of stay. Over the course of their stay, immigrants can improve their education-occupation match as they accumulate local human capital and social capital and overcome language deficits (Chiswick and Miller 2009). Hence, recently arrived immigrants tend to be more vulnerable to overeducation than longer-term immigrants (Chiswick and Miller 2009).

With respect to immigrant-native difference, immigrants in each destination country tend to be more vulnerable to overeducation than native workers because of their more circumscribed social networks (Kalfa and Piracha 2018) and because of human capital's limited transferability (Chiswick and Miller 2009). Social networks provide information about opportunities to job seekers and make referrals about prospective hires to employers (Fernandez, Castilla and Moore 2000). Because immigrants have inferior access to mainstream social networks that provide information and referral to high-level jobs (Kalfa and Piracha 2018), these social processes reduce immigrants' job prospect and may channel them away from high-status jobs and into mismatched ones.

Perhaps more important for cross-country differences in the immigrant-native gap is human capital transferability. Human capital has a country-specific component (e.g., familiarity with educational curricula and technological standards, language proficiency, other marketspecific skills, or information about how labor-market institutions operate) (Chiswick and Miller 
2009). For immigrants, education and skills acquired in the origin country are often not readily transferable in the host country (Aydemir 2011). Employers, thus, tend to undervalue and underreward foreign credentials and experience (Aydemir 2011). The issue of foreign credential recognition has been noted as a main challenge facing immigrants in Canada (Girard and Smith 2013; Reitz 2001). ${ }^{7}$ A larger supply of skilled immigrants, combined with a weaker demand for skilled labor in Canada, may induce employers to apply greater differentiation based on nativity in decision-making in Canada than in the United States. Greater nativity-based selection subsequently relegates a larger share of immigrants, relative to natives, to mismatched jobs in Canada. Hence, the immigrant-native gap in overeducation is likely to be greater in Canada than in the United States.

Hypothesis 1: University-educated immigrants in Canada are more likely to be overeducated than those in the United States, with the immigrant-native gap in overeducation greater in Canada, especially for recent immigrants.

Labor-market factors may differentially shape the risk of overeducation in the United States and Canada. Because of the larger oversupply in Canada, immigrants' overeducation may be particularly sensitive to supply-side factors, with a higher risk of overeducation associated with a larger supply of skilled immigrants in the local labor market. The large supply can intensify competition not only among university-educated immigrants but also between these immigrants and native-born workers (Aydemir and Borjas 2008; Hou and Picot 2014). In

\footnotetext{
${ }^{7}$ The non-recognition problem applies to both regulated and unregulated occupations but can be especially severe in regulated occupations in which a license from a government agency or professional organization is required to practice (Sweetman, McDonald, and Hawthorne 2015). Licensure requirements include a combination of educational requirements, formal examination, local experience and on-the-job training, and citizenship or residency. Thus, qualified immigrants cannot enter certain high-level, professional occupations unless their skills are recognized by a licensing body (which takes time), thereby pushing them into jobs for which they are overqualified.
} 
comparison, supply and demand of university-educated immigrants may be better aligned in the United States, partly due to the two-step employer-sponsored immigration system where employers sponsor immigrants first for H-1B visas and subsequently for permanent residency (Daniels 2005). As a result, many skilled immigrants in the United States secure pre-arranged jobs and avoid job search at arrival. The US demand-driven system likely promotes more successful education-occupational matching. Under such a system, supply-side conditions largely mirror the labor market's demand and capacity for skilled immigrants. We would, thus, expect a null or even negative relationship between supply and overeducation in the United States.

Hypothesis 2: The supply of university-educated immigrants is more positively linked to overeducation among immigrants in Canada than in the United States.

The supply-demand imbalance in Canada can further be understood through its immigrant selection mechanisms, specifically the government-regulated point system for screening most new skilled immigrants. Many Canadian immigrants are admitted directly from abroad, arrive without pre-established employment links, and must navigate the labor market upon arrival (Hou and Bonikowska 2018). Many may, thus, be forced to take less desirable survival jobs upon arrival. The risk of overeducation is heightened here by inadequate coordination between the government-regulated system and the labor market. This misalignment is evident in the period since the 1990s, when the skilled immigration level has increased steadily, regardless of fluctuations in demand for skilled workers, especially in the high-tech sector (Hou 2013). At the high-tech boom's peak, immigrants were relatively well placed. During the high-tech bust in the early 2000s, however, labor demand in this sector fell, resulting in a substantial deterioration in immigrants' labor-market outcomes. From the early 2000 s to the 
mid-2010s, economic growth in Canada was driven primarily by resource-based industries, as well as construction, transportation, and service sectors. These growing sectors are generally not high-tech intensive and have limited demand for highly educated workers (Baldwin and Willox 2016; Beaudry, Green, and Sand, 2016). This supply-demand imbalance tends to adversely affect immigrants' labor-market outcomes, especially new entrants to the labor force.

To assess the role of employer selection in matching educated immigrants with labormarket demand, this article compares the overeducation level between skilled immigrants admitted through different mechanisms in Canada. Although most skilled immigrants to Canada are admitted through the point system, there are other mechanisms, such as the Canadian experience class (CEC), in which immigrants are jointly selected by employers and the point system (Pandey and Townsend 2011). The CEC is not strictly the same as the US two-step employer-sponsored immigration system but is recognizably similar. Introduced in 2008, the CEC targets skilled temporary foreign workers or international students who have held a highskilled job in Canada for at least one year before applying for permanent residency (Pandey and Townsend 2011). Having worked for Canadian employers, CEC applicants then go through the point system for permanent residency. They are subject to a shorter (separate) queue than applicants applying directly from abroad through the point system (the federal skilled worker program, or FSWP) (Pandey and Townsend 2011). The main difference between CEC immigrants and FSWP immigrants is that the former were selected and evaluated by Canadian employers before applying for permanent residence.

We expect the overeducation risk to be reduced for CEC immigrants (who first go through employer selection) relative to FSWP immigrants (who are solely selected via the point system) for several reasons. First, employer selection is likely more effective in meeting 
employers' needs than government selection (Hou and Bonikowska 2018). Furthermore, the CEC mechanism simultaneously helps immigrants avoid job search at arrival and provides employers with better information about immigrants' skills, both of which are likely to improve labormarket outcomes. A similar comparison cannot be conducted in the United States because data on class of entry are not available.

Hypothesis 3: In Canada, immigrants admitted purely through the point system are more likely to be overeducated than those who also went through employer selection.

\section{DATA, MEASURES AND METHODS}

\section{Data}

Data analyzed in this article are from Canada's 2016 Census of Population 25\% sample micro data file (Statistics Canada 2017) and the pooled 2014, 2015, and 2016 American Community Surveys (ACS) from IPUMS (Ruggles et al. 2017). We pooled three years of ACS data to obtain comparable sample size with the Canadian census. The analyses focus on individuals who are aged 25-64, who have at least a Bachelor's degree, and who worked in the year prior to the census/survey date. We excluded new immigrants who arrived in the census/survey year because of the different data collection procedures in the ACS and Canadian census. ${ }^{8}$ After these restrictions, our samples consist of 370,045 immigrants in Canada and 223,608 immigrants in the United States.

\footnotetext{
${ }^{8}$ The 2016 Canadian Census was collected on May $10^{\text {th }}$. New immigrants who arrived after the census date were not captured. In comparison, the ACS was collected each month and thus captured immigrants who arrived throughout the survey year. This exclusion dropped 4,843 immigrants in Canada and 3,074 immigrants in the U.S.
} 


\section{Measures}

\section{Overeducation}

The key outcome variable is overeducation. It is a three-category variable distinguishing overeducation, marginal overeducation, and education-occupation match. Overeducation is defined as situations when individuals with at least a Bachelor's degree work in occupations that require only a high-school degree or less. ${ }^{9}$ Marginal overeducation refers to situations when individuals with at least a Bachelor's degree work in occupations that require some postsecondary education below a Bachelor's degree. Separating overeducation and marginal overeducation is important since overeducated workers experience lower earnings and subjective well-being than marginally overeducated workers (Frank and Hou 2017).

To construct the overeducation variable, we need to determine an occupation's required education and use three alternative measures, allowing us to evaluate the robustness of the results. We first use the "job analysis" approach, which is based on evaluations of occupations provided by professional job analysts in the field (Hartog 2000). For this approach, we constructed two measures, matching the data to the US scheme and Canadian scheme, respectively. The US scheme provides information on the educational requirement by detailed occupation assigned by the BLS. BLS economists assigned the typical education level necessary for each six-digit Standard Occupational Classification (SOC) category: doctoral or professional degree; master's degree; Bachelor's degree; associate's degree; postsecondary non-degree award;

\footnotetext{
${ }^{9}$ We do not distinguish advanced degrees (i.e., master's, $\mathrm{PhD}$, or professional degrees) from Bachelor's degree because whereas the US Bureau of Labor Statistics (BLS) distinguishes different degree levels (e.g., BA, MA, PhD) in assessing educational requirement of occupations, the Canadian National Occupational Classification does not. Also, according to the BLS, relatively few occupations require advanced degrees: among jobs that require at least a Bachelor's degree, $81 \%$ require a Bachelor's degree, $7 \%$ require a Master's, and $12 \%$ require a $\mathrm{PhD}$.
} 
some college, no degree; high school diploma or equivalent; or no formal educational credential. The 2014 version of BLS scheme was used in the study.

The Canadian scheme is based on the educational levels assigned by Employment and Social Development Canada for about 500 occupational groups (from over 30,000 job titles) in the 4-digit National Occupation Classification (NOC) categories. Skill level in the NOC is defined primarily by the amount and type of education and training required to enter and perform an occupation's duties. Four skill levels are identified in NOC: level A, university degree (bachelor's, master's, or doctorate); level B, some post-secondary education; level C, high school graduation or some job-specific training; and level D, some secondary/elementary education and on-the-job training. The NOC does not assign specific educational levels to management occupations. For this article, senior management occupations and specialized middle management occupations were treated as skill level A, while middle management occupations in retail, wholesale trade, customer services, transportation, production, and utilities were treated as skill level B. The 2016 version of NOC scheme was used.

The third measure was based on required educational level reported by job incumbents in an occupation from the $\mathrm{O}^{*} \mathrm{Net}$ data (20.1 version, 2015). For each of over 800 occupations, O*Net lists the percentage distribution of 12 categories of required education, ranging from less than a high school diploma to doctoral degree and post-doctoral training.

To keep the analysis consistent, occupation's educational requirements are grouped into three categories in all three measures: university education (bachelor's, master's, or doctorate degree), some post-secondary education, and high-school or less. For both the BLS and NOCbased measures, each occupation has one required educational level. For O*Net, the mode education level (i.e., the most prevalent level among the three aggregated education categories 
from the distribution) was chosen as the required educational level. Mode is preferred over mean because mean is more sensitive to technological change and to outliers (Kiker, Santos, and Oliveira 1997; Verhaest and Omey 2006)

The educational requirements from these three measures are linked to occupations in the ACS and Canadian census. The ACS uses the same SOC scheme as the BLS. However, some SOC codes in the ACS are missing the last 2, 3, or 4-digits. For these incomplete SOC codes, the linkage was conducted at a higher available digit level after aggregating BLS educational requirement to the corresponding higher SOC digit level. The mode educational level among the more detailed digits was chosen for the higher digit level. The linkage between $\mathrm{O} * \mathrm{Net}$ occupation codes and SOC was done through a crosswalk provided by $\mathrm{O}^{*}$ Net. ${ }^{10}$ The BLS and O*Net measures were applied to the Canadian census based on a concordance between the sixdigit SOC codes and the four-digit 2011 NOC codes (which has the same structure as the 2016 NOC). This concordance drew on the similarity of the occupational descriptions in the SOC and NOC (see Frenette and Frank 2017 for details). The same concordance was used to apply NOC educational requirements to the ACS.

\section{Labor Market Supply and Demand Factors}

We created several supply and demand factors at the regional level to predict overeducation among university-educated immigrants in the United States and Canada. The US regions are based on the 449 Super Public Use Microdata Area (PUMASUPR) in the IPUMS. ${ }^{11}$ The

\footnotetext{
${ }^{10} \mathrm{https}$ ://www.onetonline.org/crosswalk/SOC/ (last accessed October 2, 2019)

${ }_{11}$ We conducted sensitivity analyses, using metropolitan areas as the regional units. There are 260 metropolitan areas in the ACS and 152 census metropolitan areas and census agglomeration areas in Canada. Regression results were qualitatively similar from the two sets of measures. For the main results, we used PUMASUPR for the United States and economic regions for Canada, as these regional units
} 
Canadian regions are based on the 76 Economic Regions (the three small economic regions for the three territories were combined).

The supply factors include the share of university-educated recent immigrants (who arrived within 10 years) in the total adult population and the share of university-educated longterm immigrants (who arrived more than 10 years ago) in the total adult population of the regional labor market. The demand factor is measured by the share of native-born workers in knowledge industries - defined by an industry's research and development activity and its workforce's educational attainment in the regional labor market. Knowledge industries include 22 four-digit NAICS (North American Industry Classification System) industries covering engineering and science-based manufacturers, telecommunications, data processing, computer systems design, and consulting services (Clendenning 2000). ${ }^{12}$ We used native-born workers to calculate the demand factor because their conditions were less sensitive to the supply of immigrants and to cyclical fluctuations than those of immigrants, thus better capturing economic need.

\section{Control Variables}

We included several individual-level demographic characteristics as control variables, including age, gender $($ male $=0$, female $=1)$, graduate degree $($ Bachelor's degree $=0$, graduate degree $=1$, marital status (married, divorced or separated or widowed, never married), years since immigration, language skills, place of degree, and immigrant source region. For both Canada and the United States, immigrant source regions were classified into 14 categories: North America,

cover the entire countries, whereas metropolitan areas cover about 78\% (United States) to $80 \%$ (Canada) of the national population.

${ }^{12}$ The same NAICS is also used in ACS. The classified knowledge industries overlap closely with the technology industries classified by US Bureau of Labor Statistics. 
Central America, Caribbean, South America, Northern Europe, Western Europe, Southern

Europe, Eastern Europe, Africa, South Asia, Southeast Asia, East Asia, West Asia, and other.

We control for both language skills and place of degree because they are key factors influencing immigrants' labor-market outcomes (Chiswick and Miller 2009; Lancee and Bol 2017). We define language skills, using information on the language spoken at home. In the United States, we distinguish those speaking English versus other languages at home. In Canada, we distinguish those primarily speaking English outside Quebec or speaking French in Quebec versus other languages. For place of degree, we measure whether the immigrant received his/her highest degree in the United States or Canada. For the United States, this variable was derived from data on age at immigration and years of school (foreign-educated if years of schooling +6 $<$ age at immigration). In the Canadian data, the information is directly available.

\section{Methods}

We first show descriptive statistics of the distribution of overeducation, marginal overeducation, and occupation-education match for recent immigrants, long-term immigrants, and native-born workers in each country. Including native-born workers allows us to establish a baseline of labor market conditions in the two countries. We then ran multinomial regression models to examine cross-country difference in the level of overeducation (the first hypothesis) after controlling for a range of demographic and socioeconomic factors. In these analyses, we pooled the Canadian and US data separately for native-born workers, recent immigrants, and long-term immigrants. ${ }^{13} \mathrm{We}$

\footnotetext{
${ }^{13}$ In addition to the basic demographic and socioeconomic variables, the regression model for native-born workers also controlled for race. Racial grouping in Canada is based on responses to the Canadian census question on "visible minority" membership: "Is this person: White, Chinese, South Asian (e.g., East Indian, Pakistani, Sri Lankan, etc.), Black, Filipino, Latin American, Southeast Asian (e.g., Vietnamese, Cambodian, Malaysian, Laotian, etc.), Arab, West Asian (e.g., Iranian, Afghan, etc.), Korean, Japanese, or other?" Whites include those who self-identified as "white" only and exclude individuals who reported
} 
incorporated weights in combining data from the two countries. Both the ACS and Canadian Census micro-data file contain weights to compensate for different sampling rates of different segments of the populations. In our regression models with pooled ACS and Canadian Census data, we standardized the weights so that the standardized weights' sum is the same in both data sets and equal to the smaller data set's sample size. Standardizing these weights avoids an overestimation of the critical level while maintaining the same distributions as those of nonstandardized weights. It also ensures that data from each country contribute equally to the coefficient estimates in the models with pooled data.

To test the second hypothesis, we pooled the immigrant sample in the United States and Canada (separately for recent immigrants and long-term immigrants) and estimated multilevel multinomial logit models predicting overeducation among immigrants based on supply and demand factors (controlling for individual characteristics). Specifically, we used robust variance estimation to account for correlated errors among observations within a regional labor market and unequal variances across regional labor markets (Steenbergen and Jones 2002). Robust variance estimation is equivalent to a random-intercept model within the framework of Hierarchical Linear Models (Raudenbush et al. 2000). Weights were applied the same way as described above.

To test the third hypothesis, we disaggregated immigrants in Canada by different selection mechanisms and compared their corresponding overeducation levels via weighted multinomial logit models, as described in the analysis of the first hypothesis. We identify immigrants' admission categories in Canada by linking the Canadian census with the Immigrant

themselves as both white and one or more minority groups. Racial groups are similarly defined for the US data. To be consistent with the "white" category in Canada, we excluded people with Arabic and West Asian origins from "whites" in the US data and group them with Asian. For both countries, the variable was coded into five categories: white, black, Latino, Asian, and others. 
Landing file. ${ }^{14}$ The analysis on overeducation by immigrant categories focuses on recent immigrants who arrived in Canada between 2006 and 2015. There is no measure of selection mechanisms in the US data that allows a direct evaluation of the question for immigrants in the United States.

\section{RESULTS}

\section{Descriptive Statistics}

Table 1 compares the demographic characteristics of university-educated recent and long-term immigrant workers in Canada and the United States. Relative to their counterparts in the United States, recent immigrants to Canada were older and more likely to be women and married.

University-educated immigrants in the United States were more likely to have a graduate degree and to have received their highest degree in the destination country but less likely to speak the official language at home. In general, the majority of immigrants in both countries received their highest degree abroad. In terms of source regions, Asia was the main source region of universityeducated recent immigrants to both countries. South Asia (e.g., India) was over-represented in the United States, as was East Asia, although to a lesser degree. Southeast Asia and West Asia were over-represented in Canada. The next largest sending regions were Europe and Africa in Canada and Latin America and Europe in the United States.

[Table 1 about here]

\footnotetext{
${ }^{14}$ This file contains the administrative records of all immigrants to Canada since 1980. The information includes immigrant characteristics at the time of arrival, such as age, education, marital status, source country, official language, and immigration category.
} 


\section{Cross-country Differences in Overeducation among Immigrant and Native-born Workers}

Table 2 presents the level of overeducation of university-educated workers. The results are separated by immigration status (native-born, recent immigrants, and long-term immigrants) in the United States and Canada. The left panel displays the unadjusted results. The right panel displays the predicted probabilities based on multinomial logit models pooling the Canadian and US data for each subsample (native-born, recent immigrants, and long-term immigrants), while controlling for the individual characteristics listed in Table 1. The predicted values are based on the means for continuous control variables and proportional distributions for categorical variables in the sample for each model. We present results from three alternative definitions of overeducation, based on standards derived from BLS, NOC, and O*Net. Within each definition, the overeducation variable has three categories that sum to $100 \%$ : overeducation, marginal overeducation, and education-occupation match. All adjusted US-Canada differences based on multinomial models (right panel) are significant at the 0.001 level. We focus on interpreting the adjusted results from the BLS definition.

[Table 2 about here]

The results show large cross-country differences. Immigrants in Canada faced a heightened risk of overeducation relative to their US counterparts. Among recent immigrants with at least a Bachelor's degree, $42 \%$ in Canada were employed in jobs that required at most a high-school education (overeducated). In comparison, only $29.3 \%$ of recent skilled immigrants in the United States were overeducated. The cross-country difference regarding the level of marginal overeducation among recent immigrants was also larger in Canada, though to a lesser degree. 
In both countries, there is a notable gap in the rate of overeducation between immigrant and native-born workers. What is striking is that the immigrant-native gap is much greater in Canada than in the United States. The unadjusted and adjusted results are generally similar, although the cross-country differences in overeducation become slightly smaller after the adjustment. As seen in the right panel of Table 2 (BLS definition), the predicted probability of overeducation was $42 \%$ among recent immigrants in Canada and $22.9 \%$ among native-born workers, a difference of 19 percentage points. In comparison, the immigrant-native difference was relatively small in the United States: $29.3 \%$ for recent immigrants and $25.6 \%$ for native-born workers, a gap of 3.7 percentage points. The immigrant-native difference regarding the rate of marginal overeducation was also larger in Canada (4.5 percentage points) than in the United States ( 0.5 percentage points), but this difference is smaller than that in overeducation.

The risk of overeducation among long-term immigrants is slightly higher in Canada than in the United States (29.4\% vs. $27.4 \%$ ) but much smaller in magnitude than the cross-country difference for recent immigrants. Also, the difference between native-born workers and longterm immigrants is larger in Canada, but this difference is less pronounced than that between recent immigrants and native-born workers. The smaller cross-country difference among longterm immigrants may suggest that recent immigrants in Canada experience a higher level of transition out of overeducation and into matched jobs than do their US counterparts, partly reflecting their higher initial overeducation risk. ${ }^{15}$

Among native-born workers, those in Canada had a somewhat lower overeducation rate than those in the United States (25.6\% in the US vs. $22.9 \%$ in Canada). The cross-national

\footnotetext{
${ }^{15}$ Cohort differences could not account for the difference between recent and long-term immigrants in Canada. For instance, the overeducation rates based on NOC for recent immigrants were $32 \%$ in 2001 and $36 \%$ in 2006, both within 3 percentage-point difference from the rate of $35 \%$ in 2016.
} 
difference among native-born workers, however, is in the opposite direction of the difference among immigrants and smaller in magnitude. We also see that even among native-born workers, overeducation is quite prevalent in both countries.

The three alternative measures yield substantively similar results, but there were some differences in the overeducation distributions. For both countries, the BLS definition produced the highest overeducation rates and lowest marginal overeducation rates. The NOC definition produced the largest marginal overeducation rates and lowest education-occupation match rates. The $\mathrm{O}^{*}$ Net definition produced the highest education-occupation match rates, possibly related to the fact that the educational requirement was reported by job incumbents. Despite these differences, the dissimilarity in overeducation between immigrants in the two countries and between immigrants and native-born workers remained consistent across the three alternative measures. Overall, the results are consistent with Hypothesis 1.

\section{Cross-country Differences in the Role of Supply and Demand Factors}

Table 3 shows the descriptive statistics of the supply and demand-side factors, separately for the recent immigrant and long-term immigrant sample. The share of university-educated recent immigrants in the regional adult population was much higher in Canada than in the United States, as was the share of university-educated long-term immigrants, though to a lesser extent. While Canada had a greater supply of skilled immigrants, the demand for skilled workers favored the United States. This difference was evident in the share of native-born workers in knowledge-based industries in the regional labor market, which was notably higher in the United States than in Canada. Taking supply and demand factors together, Canada appeared to have a relative oversupply of university-educated immigrants. 
[Table 3 about here]

The left panel of Table 4 presents results from the multilevel multinomial logit models predicting the likelihood of overeducation and marginal overeducation for recent immigrants in Canada and the United States in a pooled sample. Education-occupation match is the base category. The table is based on the BLS definition. The same set of models was estimated using the NOC and $\mathrm{O}^{*}$ Net definitions, and the results were largely consistent (tables available upon request). The table displays coefficients (log odds) associated with a covariate while controlling for other covariates in the model.

There is a significantly higher risk of overeducation for recent immigrants in Canada than in the United States. In the pooled US and Canadian sample, being young, female, and separated, divorced, or widowed were associated with a higher likelihood of overeducation in both countries. Having a graduate degree protected recent immigrants from overeducation, as did a longer duration of residence in the host country. Better language skills, as measured by whether immigrants spoke official language at home, reduced overeducation in the two countries. Recent immigrants who obtained their highest degree abroad experienced heightened risk of overeducation. Compared with immigrants from Northern Europe (the reference group), North America, Western Europe, and Oceania, immigrants from Central America, the Caribbean, South America, Southern Europe, Eastern Europe, Africa, and Asia all had considerably higher rates of overeducation. The results for marginal overeducation are largely similar to the patterns just described.

[Table 4 about here]

Turning to structural factors in the labor market, the demand-side factor's role was as expected and substantively similar across countries. A higher share of workers in knowledge- 
based industries reduced the risk of overeducation and marginal overeducation for recent immigrants in both the United States and Canada, as indicated by the significant and negative coefficient of this variable. The significant and negative interaction term between the demand factor and country dummy variable for overeducation indicates that the demand-side factor's role in shaping overeducation was stronger in Canada. The interaction term for marginal overeducation was nonsignificant, pointing to a similar role of labor market demand in shaping marginal overeducation among recent immigrants in the two countries.

By contrast, the supply of university-educated recent immigrants was distinctly associated with overeducation in the two countries. This supply factor was not significantly associated with overeducation in the United States (i.e., the main effect of this variable was nonsignificant). It was even negatively related to marginal overeducation, suggesting that a higher share of educated immigrants was actually associated with a lower risk of marginal overeducation for recent immigrants in the United States. However, the interaction term between supply and the country dummy variable is significant and positive, pointing to a positive association between the supply of skilled immigrants and overeducation in Canada. In other words, a large supply of highly educated immigrants significantly increased the likelihood of overeducation for recent immigrants in Canada but not in the United States. The cross-country difference is clearly demonstrated in Figure 1, and the difference also holds for marginal overeducation.

[Figure 1 about here]

These results are consistent with Hypothesis 2, suggesting that the relatively large inflow of skilled immigrants in Canada likely leads to strong competition among recent immigrants. This competition imposes substantial barriers for immigrants in Canada to secure well-matched 
jobs. In the United States, employer selection leads to a closer alignment between the relatively small supply of skilled immigrants and the demand for university-educated immigrant workers. Hence, the supply of high-skilled immigrants is largely demand driven. The share of universityeducated immigrants in a regional labor market essentially reflects variations in demand for university-educated immigrants, which in our analysis gave rise to a null or negative association with overeducation. University-educated immigrants in the United States may be attracted to areas with high demand or other qualities not fully captured by our demand measure, such as places with fast growth in high-skilled jobs (growth in demand, not just stock in demand) (Cadena and Kovak 2016). The concentration of US immigrants in high-growth areas can also lead to a null or negative relationship between immigrant supply and overeducation.

The right panel of Table 4 shows the multilevel multinomial models for long-term immigrants in the United States and Canada. Similar to recent immigrants, the demand factor is negatively associated with overeducation in both countries, though its role becomes negligible for marginal overeducation among long-term immigrants. Unlike recent immigrants, the share of university-educated long-term immigrants was not significantly associated with the risk of overeducation in either country. This result suggests that long-term immigrants are not particularly sensitive to supply-side factors, presumably because they have accumulated local experience that allows them to find high-skilled jobs.

\section{The Role of Immigrant Selection Mechanisms}

One probable reason for the large cross-country difference in overeducation among recent immigrants is the distinct employer selection mechanisms adopted in the two countries. Skilled immigrants in the United States are much more likely to be selected by employers than are their 
counterparts in Canada. The Canadian experience class (CEC) represents a main employerselection mechanism in Canada. To obtain a more complete picture, we also examine another (partial) employer-selection mechanism in Canada, the provincial nominee programs (PNP), which allows provinces to nominate immigrants with specific skills to meet provincial needs (e.g., population growth and labor shortage) (Pandey and Townsend 2011). This program has become a main pathway for low-skilled temporary foreign workers to gain permanent residence status in Canada (Hou and Picot 2016), although some high-skilled foreign workers also use this avenue to gain permanence residence (Prokopenko and Hou 2018). By the early 2010s, about $60 \%$ of PNP principal applicants had Canadian work experience before obtaining permanent residence (Hou and Picot 2016).

We compare the outcomes of these two categories of immigrants in Canada (CEC and PNP) with the outcomes of those admitted under the federal skilled worker program (FSWP, i.e., the point system).${ }^{16}$ The results are presented in Table 5, which is based on multinomial logit regressions with the three-category overeducation variable as the outcome and the three-category admission class variable as the key predictor (FSWP as the reference category). The left panel presents the observed results, while the right panel (adjusted results) shows predicted probabilities of overeducation based on multinomial regressions while controlling for individual characteristics listed in Table 1.

\footnotetext{
${ }^{16}$ Among recent immigrants (i.e., those who had been in Canada for 10 years or less), CEC immigrants were on average 7 years younger than FSWP immigrants, followed by PNP immigrants (about 4 years younger). CEC immigrants had the shortest duration of residence in Canada (about 3 years), compared with PNP (4.5 years) and FSWP immigrants (6.9 years). These differences are partly because the CEC was introduced more recently than the other categories. A lower share of PNP immigrants had a graduate degree (35\%) than FSWP (50\%) and CEC (40\%). The sample size is 7,400 for CEC, 19,700 for PNP, and 53,200 for FSWP.
} 
The results demonstrate that university-educated recent immigrants admitted via CEC had a much lower rate of overeducation and a higher rate of education-occupation match than did FSWP immigrants. The differences between these two classes remain similar after controlling for differences in individual characteristics. For example, based on the BLS definition, the predicted probability of overeducation was $28.6 \%$ for recent CEC immigrants and $37 \%$ for FSWP immigrants in Canada. The rate of overeducation for CEC immigrants is comparable to that of native-born workers (in Table 2). The estimates based on alternative definitions were similar. All adjusted differences between CEC and FSWP immigrants are significant at the 0.001 level. These results are consistent with Hypothesis 3 that employer selection improves educationoccupation match among recent skilled immigrants.

[Table 5 about here]

In comparison, PNP immigrants had a higher rate of overeducation (43.1\%) than did FSWP immigrants. All adjusted differences between PNP and FSWP immigrants are significant at the 0.001 level. The higher overeducation rate for PNP immigrants is likely because the occupations selected for PNPs are often low and semi-skilled, whereas our sample contains immigrants with at least a bachelor's degree. PNP immigrants' disadvantage may also be attributed to their demographic characteristics, particularly their lower probability of having a graduate degree and higher probability of coming from Southeast Asia, where immigrants are largely funneled into jobs that do not require a college degree (e.g., domestic care). It is also probable that some university-educated foreign workers use PNPs as an easier route for immigration than the point system. Some of them may later transition out of the jobs for which they were initially selected. 
The large difference between CEC and PNP immigrants suggests that employee selection does not always lead to superior labor-market outcomes for skilled immigrants. The beneficial effect only becomes evident when employer selection is linked to high-skill jobs, as is the case for most H1B immigrants in the United States and CEC immigrants in Canada. Employer selection may not benefit skilled immigrants when it is linked to lower-level jobs and is used to fill precarious jobs with limited opportunities for occupational mobility (Hou and Bonikowska 2018).

\section{DISCUSSION}

This article examines the prevalence of overeducation among immigrants in the United States and Canada, as well as the structural factors that shape this phenomenon. We make several contributions to the immigration literature. First, by explicitly comparing the level of overeducation in the two countries, we provide strong evidence that highly educated immigrants in Canada have a much higher risk of overeducation than do their US peers. Especially striking is the immigrant-native difference. Whereas immigrants in both countries are more likely than native-born workers to experience an education-occupation mismatch, the gap is much more pronounced in Canada than in the United States. Our results are consistent across three alternative definitions of overeducation. The use of multiple measures increases our confidence about the robustness of the results, which cast doubt about the key premise of a merit-based immigration system - namely, that such a system will necessarily lead to better labor-market outcomes for immigrants (Hunt and Gauthier-Loiselle 2010).

Second, this article provides insights into how the immigration system interacts with labor markets' structural features to affect immigrants' labor-market outcomes. In particular, we 
find evidence that structural imbalances between the supply and demand for skilled workers increase the risk of overeducation among recent immigrants. In Canada, a higher supply of university-educated immigrants is positively associated with overeducation, but such an association is not present in the United States. The oversupply issue is much less severe in the United States, which has a relatively smaller supply of educated immigrants and a larger demand for skilled labor. These results provide evidence that a structural oversupply of highly educated immigrants exists in Canada and that this oversupply contributes to the overeducation problem facing recent immigrants in the country.

Third, this article explicitly examines the role of immigrant selection mechanisms in education-occupation match, using unique data available in Canada. We speculate that an employment-based immigration selection system for high-skilled immigrants, like the one adopted in the United States, is more effective at balancing immigrant supply with domestic labor-market demand. The employment-based system is a likely reason for the lower rate of overeducation among recent immigrants in the United States. We find supportive evidence by comparing employer- and government-selected immigrants in Canada: the rate of overeducation is significantly lower for recent immigrants who went through employer selection (CEC) than for those selected via only the point system (FSWP).

A discussion of limitations is in order. One possible explanation for the cross-country difference in overeducation is immigrants' differential unobserved characteristics. It is probable that the higher return to skills in the United States leads to more positive (unobserved) selectivity of immigrants in the United States that facilitates education-occupation match. We do not have information to directly adjudicate this possibility but believe it is unlikely to be a key determinant of the difference. Previous research using longitudinal data that control for 
immigrants' unobserved selectivity did not find evidence that a more positive (unobserved) selection of immigrants in the United States explains their relative labor-market advantage over immigrants in Canada. In other words, after controlling for unobserved selectivity of immigrants, US immigrants remain more economically advantaged than their Canadian counterparts (Kaushal et al. 2016). Also, our results provide unambiguous evidence that labor-market supply and demand, as well as mechanisms for immigrant selection, play important roles in shaping immigrant labor-market outcomes such as overeducation.

This article is a timely contribution to the current immigration debate, especially in light of recent pushes in the United States and some European countries to adopt a merit-based system (Pierce and Selee 2017; O'Brien 2018). In the United States, the push reflects the concern in some circles over unskilled immigrants' negative effects on the national economy and socioeconomic inequality, as well as a prevailing belief about skilled immigrants' positive contribution to economic vitality (Kaushal 2019). Nevertheless, as we show in this article, Canada's experience provides some important lessons for US and European policymakers. Meritbased immigration is not a silver bullet and can have diminishing benefits if the labor market fails to accommodate skilled immigrants and utilize their skills.

A merit-based system likely works better when it takes into consideration domestic labormarket demand. As we find, the rate of overeducation for highly educated native-born workers in the United States is already high, even more so than for their Canadian counterparts. A large influx of high-skill immigrants may intensify competition between immigrants and native-born workers, effectively aggravating the problem of overeducation for both groups. Placing immigration policies within the context of labor-market structural conditions, thus, is likely to be a more favorable and sustainable path forward. 
In practice, it is difficult for governments to match immigrant supply with macroeconomic conditions, as is evident from Canada's experience. In the past, Canada made deliberate efforts to monitor labor-market demand by including considerations (points) for filling special occupational needs. This system was phased out in the early 1990s, however, because it proved to be ineffective (Green and Green 1999). Canada's experience speaks to the inherent challenges of forecasting demand for specific sectors and occupations and then synchronizing immigration selection with these labor needs (Green and Green 1999). This difficulty is due in part to the fast pace at which labor markets can develop and the challenges of trying to bring needed immigrants in the face of those changes. Our results suggest that a practical way of bringing supply in line with demand is to rely on a mechanism closer to the one in the United States, where employers, rather than the government, select skilled immigrants. Employers have better, more timely information on the skills and occupations in high need. In this respect, a point system can be fine-tuned by incorporating an employer-selection approach, for example, by attaching greater weight to arranged employment at a level commensurate with immigrants' skills and labor-market needs.

In fact, Canada has significantly modified its point system to address their skilled immigrants' lackluster labor-market performance. The system now has a more direct connection between labor-market needs and immigrant skills (Hiebert 2019). A primary strategy has been to increase the proportion of educated immigrants whose skills are in great demand and who had Canadian work experience or are employer nominated, a tacit acknowledgement of the merit of the US two-step employment-based system. In 2015, Canada implemented a new Express Entry system, fast-tracking skilled immigrants who have Canadian work experience or have secured pre-arranged employment. Only prospective immigrants who meet the cutting-off points in the 
Comprehensive Ranking System (CRS) are invited to submit a formal application for permanent residency. The new Express Entry system is more demand driven and draws increasingly on temporary workers and foreign students as sources of new permanent residents. These policy reforms are expected to improve new immigrants' labor-market outcomes.

For the United States, it is too early to predict whether comprehensive immigration reform will take place and, if so, what the new policies will look like. The relatively high level of overeducation among both immigrants and native-born workers in the United States leaves room for public discourse about the desired level of skilled immigrants and ways to achieve it. A merit-based immigration selection system may reduce the share of family immigrants but does not necessarily improve the skill utilization of well-educated economic immigrants.

Implementing a merit-based system without fully considering the labor market demand for skilled workers or employers' role in immigrant selection runs the risk of compromising the very goal it seeks to achieve.

\section{References}

Antecol, H., D. A. Cobb-Clark, and S. J. Trejo. 2003. "Immigration Policy and the Skills of Immigrants to Australia, Canada, and the United States." Journal of Human Resources 38(1):192-218.

Aydemir, A. 2011. "Immigrant Selection and Short-Term Labor Market Outcomes by Visa Category." Journal of Population Economics 24(2): 451-475.

and G. J. Borjas. 2007. "Cross-Country Variation in the Impact of International Migration: Canada, Mexico, and the United states." Journal of the European Economic Association 5(4):663-708

— Immigrant Cohorts, 1966-2000." Canadian Journal of Economics 38(2): 641-672.

Baldwin, J.R., and M. Willox. 2016. "The Industry Origins of Canada's Weaker Labour Productivity Performance and the Role of Structural Adjustment in the 1990s and the 2000s." Analytical Studies Branch Research Paper Series, no. 373. Statistics Canada Catalogue, 11F0019M. 
Banerjee, R., A. Verma, and T. Zhang. 2018. "Brain Gain or Brain Waste? Horizontal, Vertical, and Full Job-Education Mismatch and Wage Progression among Skilled Immigrant Men in Canada." International Migration Review 1-25.

Beckhusen, J., R. Florax, J. Poot, and B. S. Waldorf. 2013. "Attracting Global Talent and then What? Overeducated Immigrants in the United States." Journal of Regional Science 53(5):834854.

Beaudry, P., D.A. Green, and B.M. Sand 2016. "The Great Reversal in the Demand for Skill and Cognitive Tasks." Journal of Labor Economics 34(1):S199-S247.

Bloemraad, I. 2006. "Becoming a citizen in the United States and Canada: Structured mobilization and immigrant political incorporation.” Social Forces 85(2):667-695.

—. 2011. " "Two peas in a pod," "apples and oranges," and Other Food Metaphors:

Comparing Canada and the United States." American Behavioral Scientist 55(9):1131-1159.

— Loosely Stitched Patchwork." In International Perspectives: Integration and Inclusion, edited by James Frideres and John Biles, 205-232. Metropolis.

Bonikowska, A., F. Hou, and G. Picot. 2011. "A Canada-US Comparison of Labour Market Outcomes among Highly Educated Immigrants." Canadian Public Policy 37(1):25-48.

Borjas, G. J. 1987. "Self-Selection and the Earnings of Immigrants." American Economic Review 77 (4):531-53.

Boyd, M. 1976. "Immigration Policies and Trends: A Comparison of Canada and the United States.” Demography 13(1):83-104.

- 2013. "Accreditation and the Labor Market Integration of Internationally Trained Engineers and Physicians in Canada." In Wanted and Welcome?, edited by T. Triadafilopoulos, 165-197. New York, NY: Springer.

- 2014. "Recruiting High Skill Labour in North America: Policies, Outcomes and Futures." International Migration 52(3):40-54.

Cadena, B. C., and B. K. Kovak. 2016. "Immigrants Equilibrate Local Labor Markets: Evidence from the Great Recession." American Economic Journal: Applied Economics 8(1):257-90.

Chiswick, B. R., and P.W. Miller. 2009. "The International Transferability of Immigrants' Human Capital." Economics of Education Review 28(2):162-169.

Clendenning, E. W. 2000. "Comparison and Reconciliation of SIC and NAICS Industry Codes Used to Define Knowledge-Based Industries (KBIs).” Prepared for Industry, Small Business 
Policy Branch.

$<$ https://www.ic.gc.ca/eic/site/061.nsf/vwapj/ComparisonReconciliation_e.pdf/\$FILE/Compariso nReconciliation_e.pdf $>$ Accessed on December 23, 2017.

Cohn, E., and S. P. Khan. 1995. "The Wage Effects of Overschooling Revisited." Labour Economics 2(1):67-76.

Cohen, Y., and Y. Haberfeld. 2007. "Self-Selection and Earnings Assimilation: Immigrants from the Former Soviet Union in Israel and the United States." Demography 44(3):649-668.

Daniels, Roger. 2005. Guarding the Golden Door: American Immigration Policy and Immigrants since 1882. Macmillan.

Fernandez, R.M., E.J. Castilla, and P. Moore. 2000. "Social Capital at Work: Networks and Employment at A Phone Center." American Journal of Sociology 105(5):1288-1356.

Ferrer, A. M., G. Picot., and W. C. Riddell., 2014. "New directions in immigration policy: Canada's evolving approach to the selection of economic immigrants." International Migration Review, 48(3), 846-867.

Frank, K. 2013. "Immigrant Employment Success in Canada: Examining the Rate of Obtaining a Job Match." International Migration Review 47(1): 76-105.

Frank, K., and F. Hou. 2018. "Over-Education and Well-Being: How does EducationOccupation Mismatch Affect the Life Satisfaction of University-educated Immigrant and NonImmigrant Workers?” Ethnicity \& Health 23(8): 884-901.

Frenette, M., and K. Frank. 2017. "Do Postsecondary Graduates Land High-skilled Jobs?" Analytical Studies Branch Research Paper Series, no. 388. Statistics Canada Catalogue, 11F0019M.

Girard, M., and M.R. Smith. 2013. "Working in a Regulated Occupation in Canada: An Immigrant-Native Born Comparison." Journal of International Migration and Integration 14(2):219-244.

Green, A. G., and D. A. Green. 1999. "The Economic Goals of Canada's Immigration Policy: Past and Present." Canadian Public Policy/Analyse de politiques: 425-451.

Greenwood, M. J., and J. M. McDowell. 1991. "Differential Economic Opportunity, Transferability of Skills, and Immigration to the United States and Canada." Review of Economics and Statistics 73(4):612-23.

Grogger, J., and G. H. Hanson. 2011. "Income Maximization and the Selection and Sorting of International Migrants." Journal of Development Economics 95(1):42-57. 
Hartog, J. 2000. "Overeducation and Earnings: Where are We, Where should We Go?" Economics of Education Review 19(2):131-147.

Hiebert, D. 2019. The Canadian Express Entry System for Selecting Economic Immigrants: Progresses and Persistent Challenges. Washington, DC: Migration Policy Institute.

Ho, M., S. Rao, and J. Tang. 2004. "Sources of Output Growth in Canadian and U.S. Industries in the Information Age." In Economic Growth in Canada and the United States in the Information Age, edited by D. W. Jorgenson, 83-165. Industry Canada Research Monograph.

Hou, F. 2013. "Immigrant Entry Earnings over the Past Quarter-Century: The roles of Changing Characteristics and Returns to Skills." Canadian Studies in Population 40 (3-4):149-163.

—, and A. Bonikowska. 2018. "Selections Before the Selection: The Earnings Advantage of Host-country Work Experience before Permanent Residence." International Migration Review 52(3):695-723.

\section{—, and Y. Lu. 2017. "International Students, Immigration and Earnings Growth: the Effect of a Pre-Immigration Host-Country University Education." IZA Journal of Development and Migration 7(5):1-24.}

- and G. Picot. 2014. "Annual Levels of Immigration and Immigrant Entry Earnings." Canadian Public Policy 40(2):166-181.

— and 2016. "Changing Immigrant Characteristics and Pre-Landing Canadian Earnings: Their Effect on Entry Earnings over the 1990s and 2000s." Canadian Public Policy 42(3):308-232.

Hunt, J., and M. Gauthier-Loiselle. 2010. "How Much Does Immigration Boost Innovation?" American Economic Journal: Macroeconomics 2(2):31-56.

Kalfa, E., and M. Piracha. 2018. "Social Networks and the Labour Market Mismatch." Journal of Population Economics 31(3):877-914.

Krogstad, Jens M., Jeffrey S. Passel, and D’Vera Cohn. 2019. 5 Facts about Illegal Immigration in the U.S. Vol. 19.

Kaushal, Neeraj. 2019. Blaming Immigrants: Nationalism and the Economics of Global Movement. Columbia University Press.

— of Relative Selection." International Migration Review 49(2):479-522.

$\longrightarrow,-$ N. Denier, J. Shu-Huah Wang, and Stephen J. Trejo. 2016. "Immigrant Employment and Earnings Growth in Canada and the USA: Evidence from Longitudinal Data." Journal of Population Economics 29(4): 1249-1277 
Kiker, B.F., M. C. Santos, and M. Mendes DE Oliveira. 1997. "Overeducation and Undereducation: Evidence for Portugal.” Economics of Education Review 16: 111-125.

Lancee, Bram and Thijs Bol. 2017. "The Transferability of Skills and Degrees: Why the Place of Education Affects Immigrant Earnings.” Social Forces 96(2):1-26.

Magalhaes, L., C. Carrasco, and D. Gastaldo. 2010. "Undocumented Migrants in Canada: A Scope Literature Review on Health, Access to Services, and Working Conditions." Journal of Immigrant and Minority Health 12(1):132.

Mattoo, A., I.C. Meagu, and C. Ozden. 2008. "Brain Waste? Educated Immigrants in the US Labor Market.” Journal of Development Economics 87(2):255-269.

McDonald, J. T., C. Warman, and C. Worswick. 2015. "Immigrant Selection Systems and Occupational Outcomes of International Medical Graduates in Canada and the United States." Canadian Public Policy 41(Supplement 1): S116-S137.

O'Brien, Matthew. 2018. "Germany's Merit-Based Immigration Plan." Accessed via https://www.immigrationreform.com/2018/10/02/germanys-merit-based-immigration-plan/

Pandey, M., and J. Townsend. 2011. Provincial Nominee Programs: An Evaluation of the Earnings and Retention Rates of Nominees. Prairie Metropolis Centre.

Picot, W. G., and F. Hou. 2003. "The Rise in Low-Income Rates among Immigrants in Canada." Analytical Studies Branch, Statistics Canada.

Pierce, S., and A. Selee. 2017. "Immigration under Trump: A Review of Policy Shifts in the Year Since the Election." Migration Policy Institute Policy Brief.

Prokopenko, E. and F. Hou. 2018. "How Temporary were Canada's Temporary Foreign Workers". Population and Development Review 44(2): 257-280.

Reitz, J. G. 2001. "Immigrant Skill Utilization in the Canadian Labour market: Implications of Human Capital Research." Journal of International Migration and Integration/Revue de l'integration et de la migration internationale 2(3): 347-378.

Raudenbush, S.W., A.S. Bryk, Y.F. Cheong, and R.T. Congdon. 2000. HLM5 Hierarchical Linear and Nonlinear Modeling. Lincolnwood, IL: Scientific Software International, Inc.

Roubein, Rachel. 2014. "Should the U.S. Adopt Canada's Immigration System? One Republican Thinks So." The Atlantic.

Ruggles, S., K. Genadek, R. Goeken, J. Grover, and M. Sobek. 2017. Integrated Public Use Microdata Series: Version 7.0 [dataset]. Minneapolis: University of Minnesota. https://doi.org/10.18128/D010.V7.0. 
Steenbergen, M. and B. Jones. 2002. "Modeling Multilevel Data Structure." American Journal of Political Science 46:218-237.

Sweetman, A., J.T. McDonald, and L. Hawthorne. 2015 "Occupational regulation and foreign qualification recognition: an overview." Canadian Public Policy 41, no. Supplement 1: S1-S13.

USCIS tables. "Number of H-1B Petition Filings Applications and Approvals, Country, Age, Occupation, Industry, Annual Compensation, and Education FY2007-FY2017" U.S. Citizenship and Immigration Services.

https://www.uscis.gov/sites/default/files/USCIS/Resources/Reports\%20and\%20Studies/Immigrat ion\%20Forms\%20Data/BAHA/h-1b-2007-2017-trend-tables.pdf Accessed on September 23, 2018.

Verdugo, R. R., and N. T. Verdugo. 1989. "The Impact of Surplus Schooling on Earnings: Some Additional Findings." Journal of Human Resources: 629-643.

Verhaest, D., and E. Omey. 2006. “The Impact of Overeducation and Its Measurement.” Social Indicators Research 77: 419-448.

Vialet, J. C., and L. M. Eig. 1990. Immigration Act of 1990 (P.L. 101-649). Washington, DC: Congressional Research Service.

Wald, S., and T. Fang. 2008. "Overeducated Immigrants in the Canadian Labour Market: Evidence from the Workplace and Employee Survey." Canadian Public Policy 34(4):457-479.

World Bank. 2017. World Development Indicators. 
Table 1 Means or proportions of individual-level predictors among universityeducated workers by immigration status, Canada and the United States

\begin{tabular}{|c|c|c|c|c|}
\hline & \multicolumn{2}{|c|}{ Recent immigrants } & \multicolumn{2}{|c|}{ Long-term immigrants } \\
\hline & Canada & US & Canada & US \\
\hline & \multicolumn{4}{|c|}{ mean or proportion } \\
\hline Age & 39.081 & 36.368 & 46.027 & 45.065 \\
\hline Female & 0.483 & 0.423 & 0.493 & 0.484 \\
\hline Graduate degree & 0.425 & 0.463 & 0.374 & 0.422 \\
\hline \multicolumn{5}{|l|}{ Racial groups } \\
\hline White & 0.220 & 0.196 & 0.326 & 0.238 \\
\hline Black & 0.072 & 0.084 & 0.052 & 0.099 \\
\hline Latino & 0.052 & 0.170 & 0.029 & 0.198 \\
\hline Asian & 0.640 & 0.499 & 0.572 & 0.414 \\
\hline Other racial minorities & 0.017 & 0.052 & 0.021 & 0.051 \\
\hline \multicolumn{5}{|l|}{ Marital status } \\
\hline Married & 0.811 & 0.683 & 0.756 & 0.697 \\
\hline Separated, divorced, or widowed & 0.053 & 0.067 & 0.087 & 0.127 \\
\hline Never marriage & 0.136 & 0.250 & 0.158 & 0.176 \\
\hline Speak official language at home & 0.501 & 0.445 & 0.621 & 0.530 \\
\hline Completed education abroad & 0.813 & 0.776 & 0.474 & 0.366 \\
\hline Years since immigration & 6.004 & 5.387 & 24.107 & 25.874 \\
\hline \multicolumn{5}{|l|}{ Source region } \\
\hline North America & 0.025 & 0.025 & 0.038 & 0.033 \\
\hline Central America & 0.017 & 0.081 & 0.014 & 0.114 \\
\hline Caribbean & 0.019 & 0.049 & 0.031 & 0.072 \\
\hline South America & 0.048 & 0.068 & 0.033 & 0.072 \\
\hline Northern Europe & 0.029 & 0.035 & 0.057 & 0.037 \\
\hline Western Europe & 0.040 & 0.036 & 0.035 & 0.049 \\
\hline Southern Europe & 0.011 & 0.021 & 0.041 & 0.019 \\
\hline Eastern Europe & 0.066 & 0.060 & 0.106 & 0.077 \\
\hline Africa & 0.118 & 0.073 & 0.086 & 0.061 \\
\hline South Asia & 0.224 & 0.262 & 0.158 & 0.129 \\
\hline Southeast Asia & 0.176 & 0.090 & 0.100 & 0.131 \\
\hline East Asia & 0.138 & 0.141 & 0.214 & 0.152 \\
\hline West Asia & 0.084 & 0.049 & 0.080 & 0.046 \\
\hline Oceania \& other & 0.006 & 0.011 & 0.006 & 0.009 \\
\hline Sample size & 146503 & 54063 & 223542 & 169545 \\
\hline
\end{tabular}

Data sources: the combined 2014 to 2016 American Community Survey and the Canadian 2016 Census 
Table 2 Overeducation among workers with at least a Bachelor's degree, aged 25 to 64, the United States (2014-2016) and Canada (2016)

\begin{tabular}{|c|c|c|c|c|c|c|}
\hline & \multicolumn{3}{|c|}{ Observed (unadjusted) } & \multicolumn{3}{|c|}{ Predicted probability (adjusted) } \\
\hline & $\begin{array}{r}\text { Native } \\
\text { born }\end{array}$ & $\begin{array}{r}\text { Recent } \\
\text { Immigrants }\end{array}$ & $\begin{array}{l}\text { Long-term } \\
\text { immigrants }\end{array}$ & $\begin{array}{r}\text { Native } \\
\text { born }\end{array}$ & $\begin{array}{r}\text { Recent } \\
\text { Immigrants }\end{array}$ & $\begin{array}{l}\text { Long-term } \\
\text { immigrants }\end{array}$ \\
\hline The United States & \multicolumn{6}{|c|}{ percent } \\
\hline \multicolumn{7}{|l|}{ US Bureau of Labour Statistics } \\
\hline Overeducation & 25.8 & 28.9 & 27.4 & 25.6 & 29.3 & 27.4 \\
\hline Marginal overeducation & 4.4 & 4.7 & 5.3 & 4.5 & 5.0 & 5.5 \\
\hline Education-occupation match & 69.9 & 66.4 & 67.4 & 69.9 & 65.8 & 67.2 \\
\hline \multicolumn{7}{|l|}{ Canadian NOC } \\
\hline Overeducation & 14.8 & 20.9 & 17.5 & 14.7 & 21.5 & 17.7 \\
\hline Marginal overeducation & 23.8 & 19.1 & 22.0 & 23.9 & 19.1 & 22.2 \\
\hline Education-occupation match & 61.4 & 60.0 & 60.5 & 61.4 & 59.5 & 60.1 \\
\hline \multicolumn{7}{|l|}{ O*Net } \\
\hline Overeducation & 17.6 & 24.0 & 20.6 & 17.3 & 24.3 & 20.7 \\
\hline Marginal overeducation & 10.1 & 8.0 & 9.9 & 10.3 & 8.3 & 10.1 \\
\hline Education-occupation match & 72.4 & 68.0 & 69.5 & 72.4 & 67.3 & 69.2 \\
\hline & & & & & & \\
\hline \multicolumn{7}{|l|}{ Canada } \\
\hline \multicolumn{7}{|l|}{ US Bureau of Labour Statistics } \\
\hline Overeducation & 22.8 & 42.3 & 29.4 & 22.9 & 42.0 & 29.4 \\
\hline Marginal overeducation & 4.6 & 9.4 & 7.4 & 4.5 & 9.0 & 7.2 \\
\hline Education-occupation match & 72.7 & 48.3 & 63.2 & 72.7 & 49.0 & 63.4 \\
\hline \multicolumn{7}{|l|}{ Canadian NOC } \\
\hline Overeducation & 13.1 & 34.6 & 21.3 & 13.2 & 34.0 & 21.1 \\
\hline Marginal overeducation & 24.9 & 27.7 & 27.2 & 24.8 & 27.7 & 27.1 \\
\hline Education-occupation match & 62.0 & 37.7 & 51.5 & 62.0 & 38.2 & 51.8 \\
\hline \multicolumn{7}{|l|}{ O*Net } \\
\hline Overeducation & 12.9 & 34.7 & 20.8 & 13.0 & 34.4 & 20.6 \\
\hline Marginal overeducation & 10.4 & 14.0 & 12.7 & 10.3 & 13.6 & 12.5 \\
\hline Education-occupation match & 76.7 & 51.3 & 66.6 & 76.7 & 52.0 & 66.8 \\
\hline
\end{tabular}

Data sources: the combined 2014 to 2016 American Community Survey and the Canadian 2016 Census Note: The adjusted numbers for the native-born are based on a multinomial model pooling the nativeborn in the US and Canada and controlling for racial groups, marital status, age, sex, and graduate degrees. The adjusted numbers for immigrants are based on multinomial models pooling immigrants (recent or established) in the US and Canada and controlling marital status, age, sex, graduate degrees, source regions, home language, foreign education, and years since immigration. All adjusted USCanada differences are significant at the 0.001 level. 
Table 3 Descriptive Statistics of supply and demand factors, the United States (2014-2016) and Canada (2016)

\begin{tabular}{|c|c|c|c|c|}
\hline & \multicolumn{2}{|c|}{ Recent immigrants } & \multicolumn{2}{|c|}{$\begin{array}{l}\text { Long-term } \\
\text { immigrants }\end{array}$} \\
\hline & Canada & US & Canada & US \\
\hline & \multicolumn{4}{|c|}{ proportion } \\
\hline $\begin{array}{l}\text { Share of university-educated recent immigrants in the } \\
\text { total adult population of the regional labor market }\end{array}$ & 0.067 & 0.037 & 0.067 & 0.033 \\
\hline $\begin{array}{l}\text { Share of university-educated long-term immigrants in } \\
\text { the total adult population of the regional labor market }\end{array}$ & 0.088 & 0.076 & 0.100 & 0.077 \\
\hline $\begin{array}{l}\text { Share of native-born workers in knowledge-based } \\
\text { industries in the regional labor market }\end{array}$ & 0.082 & 0.101 & 0.085 & 0.098 \\
\hline
\end{tabular}


Table 4 Multinomial models predicting overeducation, marginal overeducation versus education-occupation match for recent and lc immigrants with a bachelor's degree, based on the BLS definition, the United States (2014-2016) and Canada (2016)

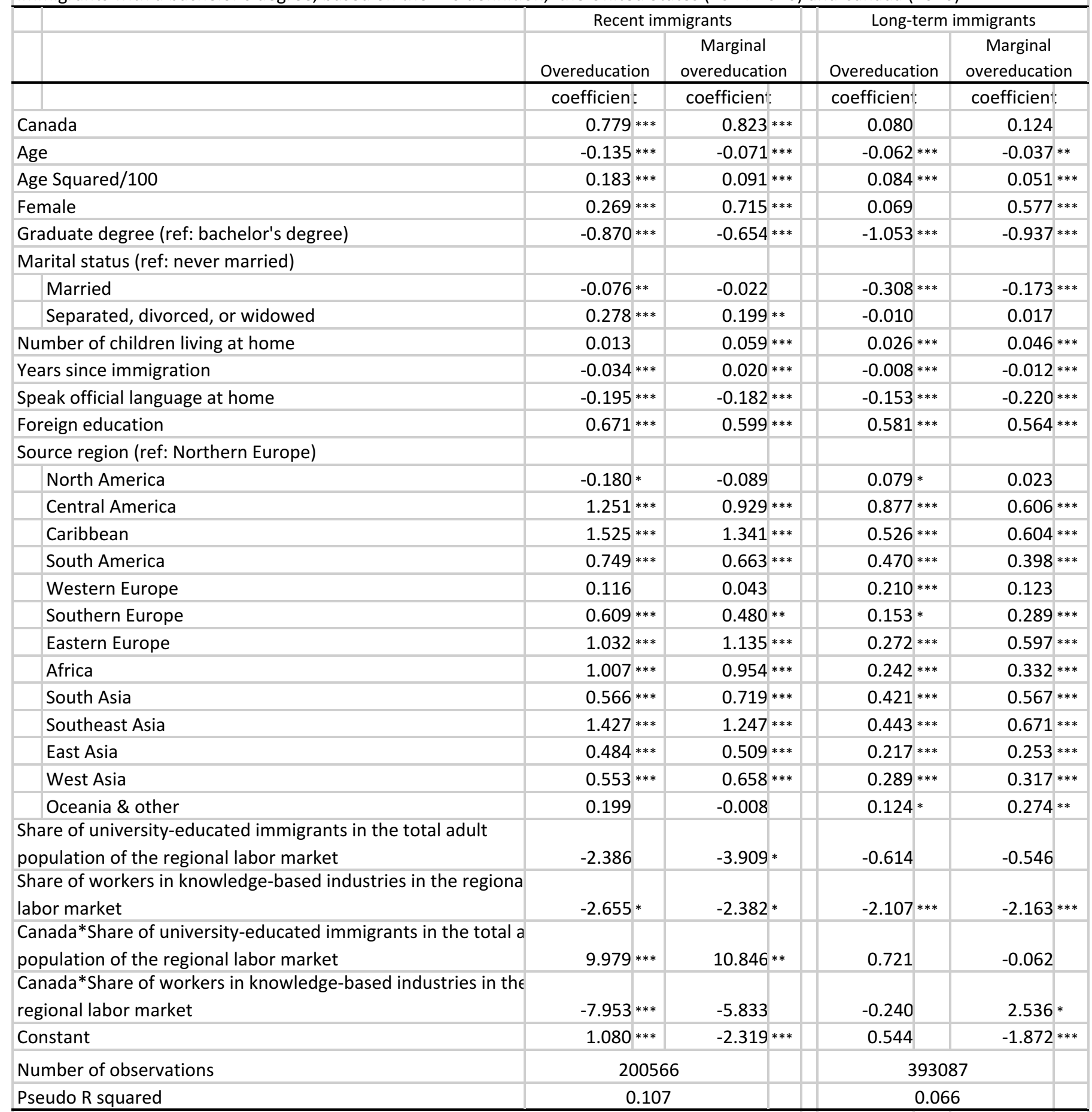

Data sources: the combined 2014 to 2016 American Community Survey and the Canadian 2016 Census

Note: the reference group for graduate degree is bachelor's degree, for marital status is never married, and for source region is Nort Europe.

* significant at $\mathrm{p}<0.05, * * \mathrm{p}<0.01, * * * \mathrm{p}<0.001$ 
Table 5 Overeducation among recent immigrants with at least a Bachelor's degree, aged 25 to 64 , by admission class, Canada, 2016

\begin{tabular}{|c|c|c|c|c|c|c|}
\hline & \multicolumn{3}{|c|}{ Observed (unadjusted) } & \multicolumn{3}{|c|}{ Predicated probability (adjusted) } \\
\hline & $\begin{array}{r}\text { Canadian } \\
\text { experience } \\
\text { class }\end{array}$ & $\begin{array}{l}\text { Provincial } \\
\text { Nominees }\end{array}$ & $\begin{array}{r}\text { Federal } \\
\text { Skilled } \\
\text { workers }\end{array}$ & $\begin{array}{r}\text { Canadian } \\
\text { experience } \\
\text { class }\end{array}$ & $\begin{array}{l}\text { Provincial } \\
\text { Nominees }\end{array}$ & $\begin{array}{r}\text { Federal } \\
\text { Skilled } \\
\text { workers }\end{array}$ \\
\hline & \multicolumn{6}{|c|}{ percent } \\
\hline \multicolumn{7}{|l|}{ US Bureau of Labour Statistics } \\
\hline Overeducation & 26.5 & 49.8 & 36.7 & 28.6 & 43.1 & 37.0 \\
\hline Marginal overeducation & 6.3 & 9.1 & 9.7 & 8.2 & 9.6 & 9.3 \\
\hline Education-occupation match & 67.3 & 41.0 & 53.6 & 63.2 & 47.2 & 53.7 \\
\hline \multicolumn{7}{|l|}{ Canadian NOC } \\
\hline Overeducation & 18.2 & 41.2 & 30.1 & 19.7 & 34.8 & 29.6 \\
\hline Marginal overeducation & 27.9 & 27.0 & 27.2 & 29.8 & 28.1 & 27.4 \\
\hline Education-occupation match & 53.9 & 31.8 & 42.8 & 50.5 & 37.2 & 43.1 \\
\hline \multicolumn{7}{|l|}{ O*Net } \\
\hline Overeducation & 19.6 & 43.3 & 28.9 & 21.3 & 36.2 & 28.7 \\
\hline Marginal overeducation & 10.6 & 13.0 & 14.3 & 12.9 & 13.7 & 14.5 \\
\hline Education-occupation match & 69.8 & 43.7 & 56.8 & 65.7 & 50.1 & 56.8 \\
\hline \multicolumn{2}{|c|}{ Data sources: the Canadian 2016 Census } & & & & & \\
\hline
\end{tabular}




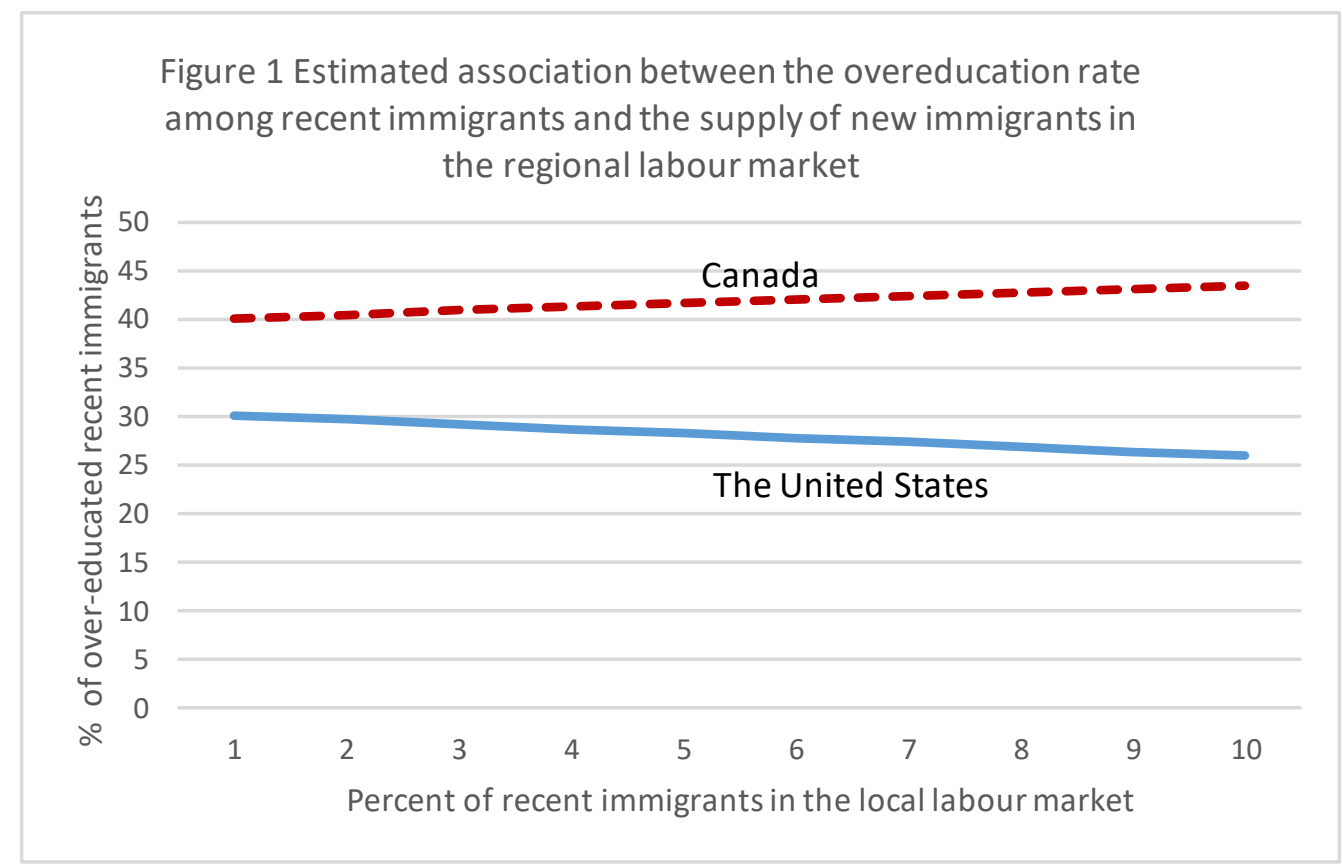

Source: Authors' estimates from the combined 2014 to 2016 American Community Survey and the Canadian 2016 Census

Note: over-education is based on US Bureau of Labour Statistics definition 